\title{
Unmet Needs in Neuroendocrine Neoplasms
}

Report of the ENETS Advisory Board

Guest Editors

Wouter W. de Herder, Rotterdam

Jaume Capdevila, Barcelona 
S. Karger

Medical and Scientific Publishers

Basel $\cdot$ Freiburg $\cdot$ Hartford $\cdot$ Oxford

Bangkok $\cdot$ Dubai $\cdot$ Kuala Lumpur .

Melbourne $\cdot$ Mexico City .

Moscow $\cdot$ New Delhi $\cdot$ Paris .

Shanghai $\cdot$ Tokyo
Disclaimer

The statements, opinions and data contained in this publication are solely those of the individual authors and contributors and not of the publisher and the editor(s). The appearance of advertisements in the journal is not a warranty, endorsement, or approval of the products or services advertised or of their effectiveness, quality or safety. The publisher and the editor(s) disclaim responsibility for any injury to persons or property resulting from any ideas, methods, instructions or products referred to in the content or advertisements.

Drug Dosage

The authors and the publisher have exerted every effort to ensure that drug selection and dosage set forth in this text are in accord with current recommendations and practice at the time of publication. However, in view of ongoing research, changes in government regulations, and the constant flow of information relating to drug therapy and drug reactions, the reader is urged to check the package insert for each drug for any change in indications and dosage and for added warnings and precautions. This is particularly important when the recommended agent is a new and/or infrequently employed drug.
All rights reserved.

No part of this publication may be translated into other languages, reproduced or utilized in any form or by any means, electronic or mechanical, including photocopying, recording microcopying, or by any information storage and retrieval system, without permission in writing from the publisher or in the case of photocopying, direct payment of a specified fee to the Copyright Clearance Center (see "General Information")

(C) Copyright 2019 by S. Karger AG,

P.O. Box, CH-4009 Basel (Switzerland)

Printed on acid-free and non-aging paper (ISO 9706)

ISBN 978-3-318-06482-7

e-ISBN 978-3-318-06483-4

\section{KARGER}




\section{Contents}

Editorial

5 Unmet Needs in the Field of Neuroendocrine Neoplasms of the Gastrointestinal Tract, Pancreas, and Respiratory System: Reports by the ENETS Group

de Herder, W.W. (Rotterdam); Capdevila, J. (Barcelona)

Conference Reports

7 Unmet Medical Needs in Pulmonary Neuroendocrine (Carcinoid) Neoplasms Baudin, E.; Hayes, A.R.; Scoazec, J.-Y.; Filosso, P.L.; Lim, E.; Kaltsas, G.; Frilling, A.; Chen, J.; Kos-Kudla, B.; Gorbounova, V.; Wiedenmann, B.; Nieveen van Dijkum, E.J.M.; Cwikla, J.B.; Falkerby, J.; Valle, J.W.; Kulke, M.H.; Caplin, M.E.; The ENETS 2016 Munich Advisory Board Participants

18 Unmet Medical Needs in Metastatic Lung and Digestive Neuroendocrine Neoplasms

Capdevila, J. (Barcelona); Bodei, L. (New York, NY); Davies, P. (London); Gorbounova, V. (Moscow); Jensen, R.T. (Bethesda, MD); Knigge, U.P. (Copenhagen); Krejs, G.J. (Graz); Krenning, E. (Rotterdam); O’Connor, J.M. (Caba); Peeters, M. (Antwerp); Rindi, G. (Rome); Salazar, R. (Barcelona); Vullierme, M.-P. (Paris); Pavel, M.E. (Erlangen); The ENETS 2016 Munich Advisory Board Participants

26 Unmet Needs in Functional and Nonfunctional Pancreatic Neuroendocrine Neoplasms

Jensen, R.T. (Bethesda, MD); Bodei, L. (New York, NY); Capdevila, J. (Barcelona); Couvelard, A. (Paris); Falconi, M. (Milan); Glasberg, S. (Jerusalem); Kloppel, G. (Munich); Lamberts, S. (Rotterdam); Peeters, M. (Edegem); Rindi, G. (Rome); Rinke, A.; Rothmund, M. (Marburg); Sundin, A.; Welin, S. (Uppsala); Fazio, N. (Milan); The ENETS 2016 Munich Advisory Board Participants

37 Unmet Needs in Appendiceal Neuroendocrine Neoplasms

Toumpanakis, C. (London); Fazio, N. (Milan); Tiensuu Janson, E. (Uppsala); Hörsch, D. (Bad Berka); Pascher, A. (Berlin); Reed, N. (Glasgow); O’Toole, D. (Dublin); Nieveen van Dijkum, E. (Amsterdam); Partelli, S. (Milan); Rinke, A. (Marburg); Kos-Kudla, B. (Katowice); Costa, F. (São Paulo); Pape, U.-F. (Berlin); Grozinsky-Glasberg, S. (Jerusalem); Scoazec, J.-Y. (Villejuif); The ENETS 2016 Munich Advisory Board Participants 
45 Colorectal Neuroendocrine Neoplasms: Areas of Unmet Need

Ramage, J.K. (Basingstoke); Valle, J.W. (Manchester); Nieveen van Dijkum, E.J.M.

(Amsterdam); Sundin, A. (Uppsala); Pascher, A. (Berlin/Muenster); Couvelard, A.

(Paris); Kloeppel, G. (Munich); The ENETS 2016 Munich Advisory Board Participants

54 Unmet Needs in High-Grade Gastroenteropancreatic Neuroendocrine Neoplasms (WHO G3)

Sorbye, H. (Bergen); Baudin, E. (Villejuif); Borbath, I. (Bruxelles); Caplin, M. (London); Chen, J. (Guangzhou); Cwikla, J.B. (Olsztyn); Frilling, A.; Grossman, A. (London); Kaltsas, G. (Athens); Scarpa, A. (Verona); Welin, S. (Uppsala); Garcia-Carbonero, R. (Madrid); The ENETS 2016 Munich Advisory Board Participants

\section{Author Index \\ 64 Subject Index}

